\title{
Influence of Steel Scrap on Microstructure and Mechanical Properties of Spheroidal Graphite Cast Iron
}

\author{
Sadato Hiratsuka ${ }^{1}$, Hiroshi Horie ${ }^{1}$, Toshinori Kowata ${ }^{1}$, Katsumi Koike ${ }^{2}$ and Kazumichi Shimizu ${ }^{3}$ \\ ${ }^{1}$ Department of Materials Science and Technology, Faculty of Engineering, Iwate University, Morioka 020-8551, Japan \\ ${ }^{2}$ Industrial Research Institute of Tochigi Prof., Kanuma 322-0011, Japan \\ ${ }^{3}$ Department of Computer and Control Engineering, Oita National College of Technology, Oita 870-0152, Japan
}

In this research, the spheroidal graphite cast iron melt was produced by using 7 kinds of steel scraps, the shredder scrap, the surface treated steel sheets, the magnetic steel sheets, the high strength steel and others. The influences of the steel scraps on microstructures and mechanical properties were studied. Zinc, chromium, antimony, nickel, aluminum and manganese were contained in the steel scraps respectively. Using the steel scrap of the used car (shredder scrap), zinc is contained in the iron castings. The antimony included in the magnetic steel sheet was found to be a powerful pearlite stabilizer. The tensile strength and the hardness of cast iron increased with the increasing pearlite percent. Also chromium included in the surface treated steel sheet and manganese in the high strength steel increase the pearlite in the matrix of cast iron.

(Received November 21, 2002; Accepted May 8, 2003)

Keywords: steel scrap, spheroidal graphite cast iron, microstructure, tensile strength, Brinell hardness

\section{Introduction}

The production of iron and steel in Japan exceeded 100 million tons in 1973, and then the production of them has hardly increased. On the other hand, the proportion of electric furnace steel produced in Japan has grown by nearly $1 \%$ every year. The production of steel has reached 104 million tons in 1997. It is considered that steel scraps tend to increase year by year. Steel scrap generated from machine parts, automobiles, construction materials and so forth. The consumption of surface treated steel sheets in the automobile industry has conspicuously increased. It is also the shredder scrap made from a used car. The consumption of magnetic steel sheets in the household electric product industry has also increased.

The production of iron castings has continued to increase and the amount of steel scrap used has increased more. Accordingly hereafter, it is inevitable that these steel sheets will be used more and more in the iron casting industry. The main raw material for iron castings has recently changed from pig iron to steel scraps.

In order to save materials and energy, the importance of steel scraps as a raw material for cast iron have been increasing in recent years. Steel scraps containing alloy elements $(\mathrm{Zn}, \mathrm{Al}, \mathrm{Cu}, \mathrm{Cr}, \mathrm{Pb}$, etc.), such as surface treated steel, high strength steel and other special steel, are particularly increasing. However, these types of steel scraps have many problems for use. In particular, a large amount of zinc produces the pinhole porosity in iron castings ${ }^{1,2)}$ and the addition of a small amount of lead in cast iron causes abnormality in graphite morphology. ${ }^{3-6)}$

Thereupon, in this research, for the purpose of determining the influences of steel scraps on the microstructure and mechanical properties (i.e., hardness, elongation and tensile strength), the following experiments were carried out.

\section{Experimental Procedure}

A high frequency induction furnace with a $12 \mathrm{~kW}, 3 \mathrm{kHz}$ motor generator unit was utilized to prepare $5 \mathrm{~kg}$ of experimental cast iron melt. The chemical compositions of steel scraps used for these experiments are shown in Table 1. The 7 kinds of steel scrap were used as the experimental material. In order to make a commercial ductile iron (FCD450), high purity pig iron was used. Carburizer and pure silicon was also used to adjust the carbon and silicon contents and ferro-manganese, ferro-phosphorus and ironsulphide were used so that the contents of manganese, phosphorus and sulfur would be the same in every melt. The melt was superheated to $1803 \mathrm{~K}$ and then nodularising treatment was carried out in a crucible using 1.6 mass $\%$ of iron-silicon (45\%)-magnesium (8\%) alloy. After the nodularising reaction subsided, the melt was post-inoculated with $0.4 \%$ ferro-silicon $(75 \%$ silicon $)$ and poured in a $\mathrm{CO}_{2}$ process sand mold at $1673 \mathrm{~K}$. The size of specimen was $\phi$ $30 \mathrm{~mm} \times 250 \mathrm{~mm}$. After the tensile test, the nodule count and the pearlite, ferrite, graphite and carbide contents and the nodularity of the tensile test specimens were measured with computerized image analyzer.

\section{Results and Discussion}

\subsection{Chemical compositions of specimens}

The chemical compositions of typical specimens are shown in Table 2.

An analysis of chemical compositions of specimens reveals that the content of trace elements lowered in the cast iron when the electrolytic iron is used as a raw material. Using the shredder scrap (A) or the surface treated steel sheets (C) (zinc coated steel sheets), zinc is contained in the cast iron. The yield rate of zinc is about $50 \%$. During melting in furnace, $50 \%$ of zinc became a zinc oxide. Using another surface treated steel sheet scrap (B), the chromium content becomes higher. The magnetic steel scrap (D) enhances the aluminum and the antimony contents in cast iron, since some magnetic steel was treated by antimony or AlN to get a fine ferrite structure. The yield rate of aluminum is about $30 \%$. The cast iron prepared with the carbon steel (E) or the high 
Table 1 Chemical composition of steel scraps and pig iron.

\begin{tabular}{|c|c|c|c|c|c|c|c|c|c|c|c|c|c|c|}
\hline & $\mathrm{C}$ & $\mathrm{Si}$ & $\mathrm{Mn}$ & $\mathrm{P}$ & S & $\mathrm{Cu}$ & $\mathrm{Cr}$ & $\mathrm{Ni}$ & Mo & $\mathrm{Sn}$ & $\mathrm{Ti}$ & $\mathrm{Al}$ & $\mathrm{Pb}$ & $\mathrm{Zn}$ \\
\hline $\begin{array}{c}\text { A,Shredder } \\
\text { Scrap }\end{array}$ & 0.014 & 0.037 & 0.102 & 0.014 & 0.001 & 0.008 & 0.019 & 0.017 & 0.006 & 0.001 & 0.018 & 0.023 & 0.003 & 0.635 \\
\hline $\begin{array}{c}\text { B,Surface } \\
\text { treated } \\
\text { steel }\end{array}$ & 0.041 & 0.08 & 0.22 & 0.026 & 0.008 & 0.020 & 0.059 & 0.030 & 0.030 & 0.001 & 0.001 & 0.035 & 0.003 & 0.00 \\
\hline $\begin{array}{c}\text { C,Surface } \\
\text { treated } \\
\text { steel }\end{array}$ & 0.01 & 0.01 & 0.14 & 0.009 & 0.007 & 0.015 & 0.035 & 0.024 & 0.004 & 0.002 & 0.015 & 0.034 & 0.003 & $\begin{array}{l}42-56 \\
\mathrm{~g} / \mathrm{mm}^{2}\end{array}$ \\
\hline $\begin{array}{c}\text { D,Magnetic } \\
\text { Steel }\end{array}$ & 0.006 & 0.549 & 0.312 & 0.030 & 0.006 & 0.01 & 0.04 & 0.014 & 0.005 & 0.002 & $<0.001$ & 0.275 & 0.002 & 0.001 \\
\hline $\begin{array}{c}\text { E,Carbon } \\
\text { Steel }\end{array}$ & 0.23 & 0.19 & 0.34 & 0.019 & 0.008 & 0.01 & 0.11 & 0.020 & $<0.001$ & 0.001 & $<0.001$ & 0.020 & 0.002 & - \\
\hline $\begin{array}{c}\text { F,Carbon } \\
\text { steel } \\
\text { scrap }\end{array}$ & 0.086 & 0.208 & 0.521 & 0.017 & 0.003 & $<0.005$ & 0.081 & 0.017 & $<0.005$ & 0.010 & 0.002 & 0.023 & $<0.01$ & $<0.005$ \\
\hline $\begin{array}{l}\text { G,Electroly } \\
\text {-tic iron }\end{array}$ & 0.0022 & $<0.0005$ & 0.0005 & $<0.005$ & 0.0001 & 0.0013 & $<0.001$ & $<0.001$ & $<0.001$ & $<0.001$ & 0.000 & 0.008 & $<0.001$ & - \\
\hline H,Pig iron & 3.95 & 0.01 & 0.08 & 0.008 & 0.006 & 0.04 & 0.016 & 0.011 & 0.001 & 0.001 & 0.000 & - & 0.001 & 0.001 \\
\hline
\end{tabular}

Table 2 Chemical composition of spheroidal graphite cast iron.

\begin{tabular}{|c|c|c|c|c|c|c|c|c|c|c|c|c|c|c|c|c|c|}
\hline & & & & & & & & & & & & & & & & \multicolumn{2}{|c|}{ (mass\%) } \\
\hline & $\mathrm{C}$ & $\mathrm{Si}$ & $\mathrm{Mn}$ & $\mathrm{P}$ & $\mathrm{S}$ & $\mathrm{Cu}$ & $\mathrm{Cr}$ & $\mathrm{Zn}$ & $\mathrm{Al}$ & $\mathrm{Pb}$ & $\mathrm{Ti}$ & $\mathrm{Sn}$ & $\mathrm{Sb}$ & $\mathrm{Ni}$ & Mo & $\mathrm{Mg}$ & $\mathrm{CE}$ \\
\hline $\begin{array}{c}\text { A,Shredder } \\
\text { Scrap }\end{array}$ & 3.53 & 2.62 & 0.32 & 0.044 & 0.008 & 0.01 & 0.019 & 0.023 & 0.002 & 0.002 & 0.015 & 0.001 & 0.000 & 0.009 & 0.002 & 0.037 & 4.35 \\
\hline $\begin{array}{c}\text { B,Surface } \\
\text { treated } \\
\text { steel }\end{array}$ & 3.66 & 2.77 & 0.44 & 0.087 & 0.008 & 0.01 & 0.060 & 0.000 & 0.020 & 0.002 & 0.002 & 0.001 & 0.000 & 0.011 & 0.002 & 0.043 & 4.54 \\
\hline $\begin{array}{c}\text { C,Surface } \\
\text { treated } \\
\text { steel }\end{array}$ & 3.65 & 2.64 & 0.32 & 0.043 & 0.008 & 0.02 & 0.032 & 0.042 & 0.021 & 0.001 & 0.011 & 0.002 & 0.000 & 0.015 & 0.004 & 0.040 & 4.45 \\
\hline $\begin{array}{c}\text { D,Magnetic } \\
\text { Steel }\end{array}$ & 3.74 & 3.08 & 0.55 & 0.077 & 0.007 & 0.01 & 0.040 & 0.000 & 0.083 & 0.003 & 0.003 & 0.002 & 0.020 & 0.007 & 0.002 & 0.052 & 4.71 \\
\hline $\begin{array}{c}\text { E,Carbon } \\
\text { Steel }\end{array}$ & 3.88 & 2.84 & 0.53 & 0.054 & 0.011 & 0.01 & 0.113 & 0.000 & 0.020 & 0.003 & 0.002 & 0.001 & 0.000 & 0.012 & 0.002 & 0.042 & 4.77 \\
\hline $\begin{array}{c}\text { F,Carbon } \\
\text { steel } \\
\text { scrap }\end{array}$ & 3.89 & 2.88 & 0.74 & 0.057 & 0.014 & 0.01 & 0.085 & 0.000 & 0.023 & 0.004 & 0.002 & 0.008 & 0.000 & 0.017 & 0.005 & 0.046 & 4.78 \\
\hline $\begin{array}{l}\text { G,Electroly } \\
\text {-tic iron }\end{array}$ & 3.68 & 2.59 & 0.21 & 0.036 & 0.003 & 0.00 & 0.016 & 0.000 & 0.007 & 0.000 & 0.002 & 0.001 & 0.000 & 0.000 & 0.001 & 0.043 & 4.49 \\
\hline H,Pig iron & 3.65 & 2.60 & 0.21 & 0.035 & 0.007 & 0.01 & 0.016 & 0.000 & 0.017 & 0.000 & 0.002 & 0.001 & 0.000 & 0.006 & 0.001 & 0.041 & 4.46 \\
\hline
\end{tabular}

strength carbon steel scrap (F) contains higher levels of chromium, manganese and tin. The yield rate of manganese and chromium is about $98 \%$ and $100 \%$ respectively.

\subsection{Microstructure Observations}

Figure 1 shows the microstructures of cast iron specimens in Table 2. The base iron $(\mathrm{H})$ without steel scrap exhibits well-formed spheroidal graphite and a nodule count of 160 counts $/ \mathrm{mm}^{2}$ with a matrix of $74 \%$ ferrite. Using the electrolytic iron, a typical Bulls-eye structure is formed. The shredder scrap and the surface treated steel sheets (zinc coated steel sheets) scrap deteriorated the morphology of spheroidal graphite. Nodule count is significantly dropped from 160 to 130 counts $/ \mathrm{mm}^{2}$, and the matrix of cast iron changes to about $31 \%$ ferrite, as illustrated in Fig. 1(A). The surface treated steel sheets and the carbon steel scraps increase the amount of pearlite. This is due to the high content of pearlite-stabilizing elements (chromium and manganese) in the material. ${ }^{7,8)}$ There is clear agreement that a chromium, tin and manganese addition to spheroidal 


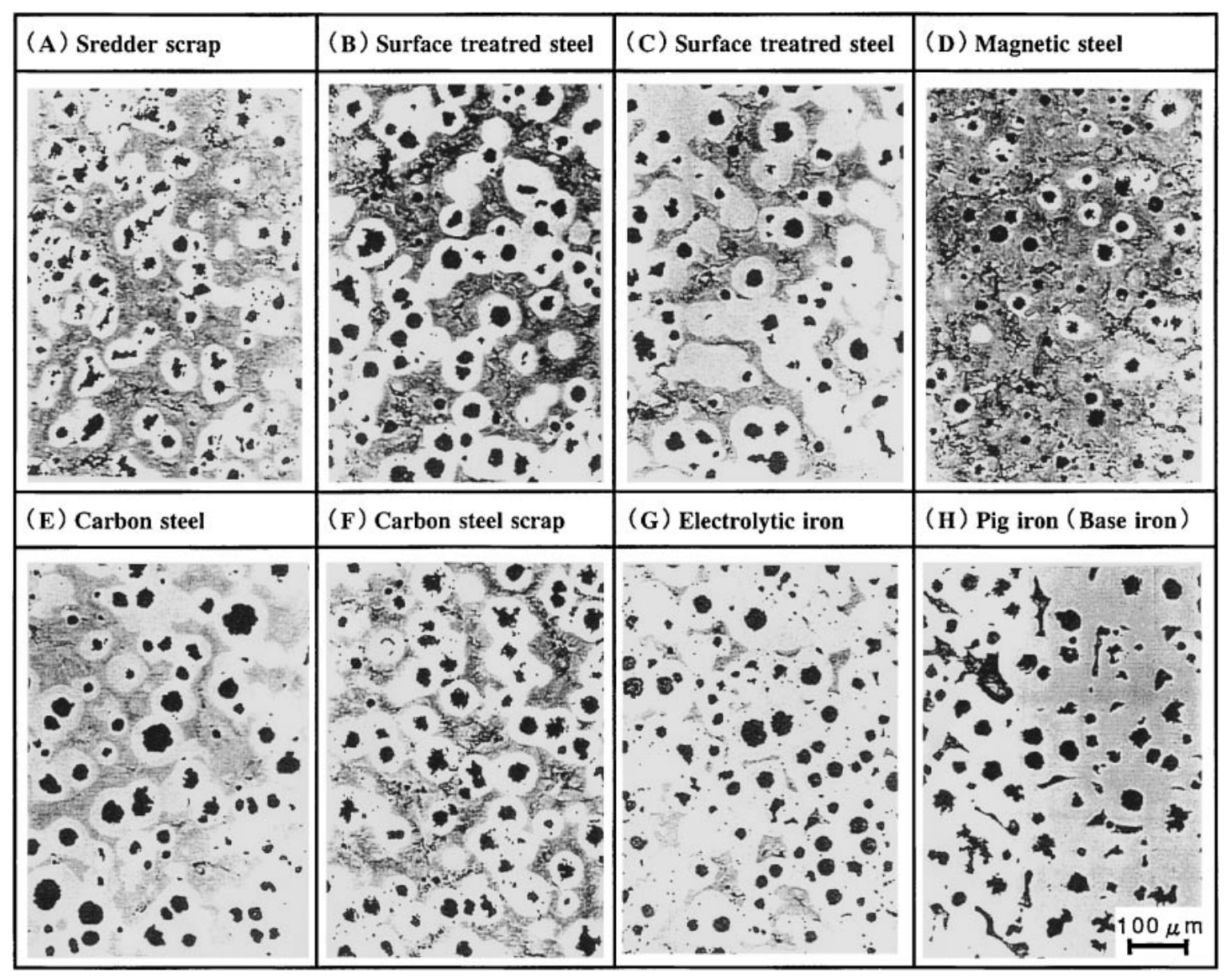

Fig. 1 Microstructure of specimens using steel scraps as a raw material.

graphite cast iron promotes the stability of pearlite. Using the magnetic steel was sufficient to convert the structure of the predominantly ferrite base casting to $87 \%$ pearlite. Antimony included in the magnetic steel scrap exhibited a pronounced pearlite stabilizing influence. ${ }^{9-11)}$ As the antimony deteriorates the morphology of spheroidal graphite, the formation of aggregated graphite was observed at austenite shell boundary. The magnetic steel scrap also produced a few star-shaped graphite. The total nodule counts slightly increased to 178/ $\mathrm{mm}^{2}$.

\subsection{Tensile strength, elongation and hardness}

The effects of each steel scraps on the tensile strength were investigated on ductile iron specimens with CE4.3-4.85. As shown in Fig. 2, the tensile strength of the base iron $(\mathrm{H})$ with CE 4.5 was $516 \mathrm{MPa}$. Tensile strength increases from 516 to $579 \mathrm{MPa}$ with decreasing CE value from 4.5 to 4.3 . Tensile strength of all specimens produced with steel scraps was generally higher than the strength of the base iron. For example, the strength of cast iron (CE 4.4) prepared with surface treated steel sheet scrap (B) was $629 \mathrm{MPa}$. In the case of the carbon steel scrap (F) and the magnetic steel sheet scrap (D) was $689 \mathrm{MPa}$ and $695 \mathrm{MPa}$ respectively. The increase in strength is a result of an increase in the amount of pearlite in the matrix.

The effects of steel scraps on the elongation values of ductile iron are shown in Fig. 3. Elongation value of the base iron $(\mathrm{H})$ increases from 16 to $24 \%$ with increasing $\mathrm{CE}$ value from 4.3 to 4.5 . Elongation values of all specimens using steel scraps as a raw material were generally lower than the elongation of the base iron. For example, the elongation value of the specimen made of surface treated steel sheets (B) was $10.6 \%$ at CE 4.4. Using the magnetic steel sheet (D), the elongation values were in $4.1-5.3 \%$. The elongation was reduced as a result of the increased amount of pearlite. The improved tensile strength and corresponding reductions in ductility produced by antimony in the magnetic steel sheet is readily understood in terms of its effect on microstructure.

The effects of steel scraps on the hardness of ductile iron are shown in Fig. 4.

Brinell hardness of the base iron $(\mathrm{H})$ increased from $157 \mathrm{HB}$ to $187 \mathrm{HB}$ with decreasing $\mathrm{CE}$ values from 4.5 to 4.3 . The Brinell hardness of every specimen prepared with steel scraps was generally higher than the hardness of the base iron. For example, the hardness of surface treated steel sheets (B) used was $197 \mathrm{HB}$.

In the case of the carbon steel scrap $(\mathrm{F})$ and the magnetic steel sheet (D) was $229 \mathrm{HB}$ and $277 \mathrm{HB}$ respectively. Using the magnetic steel sheet (D), the amount of pearlite and the hardness were the highest in specimens.

Figure 5 shows relation between the area fraction of pearlite values and Brinell hardness. The increase in hardness is a result of an increase in the amount of pearlite in the matrix. 


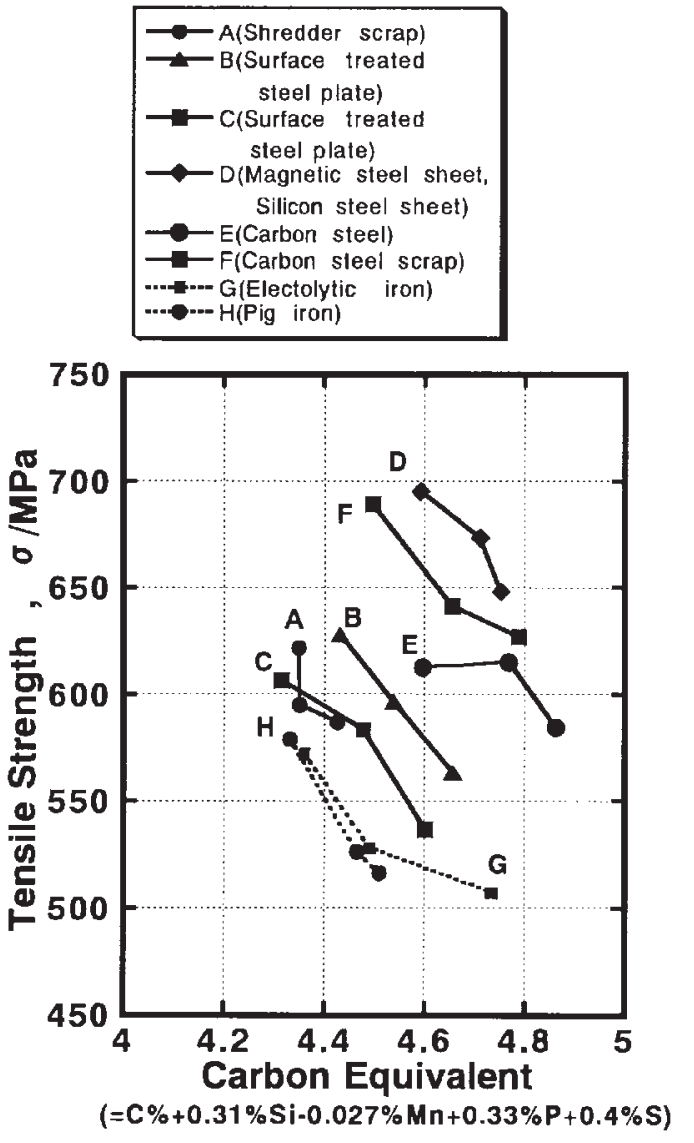

Fig. 2 Relation between tensile strength and carbon equivalent.

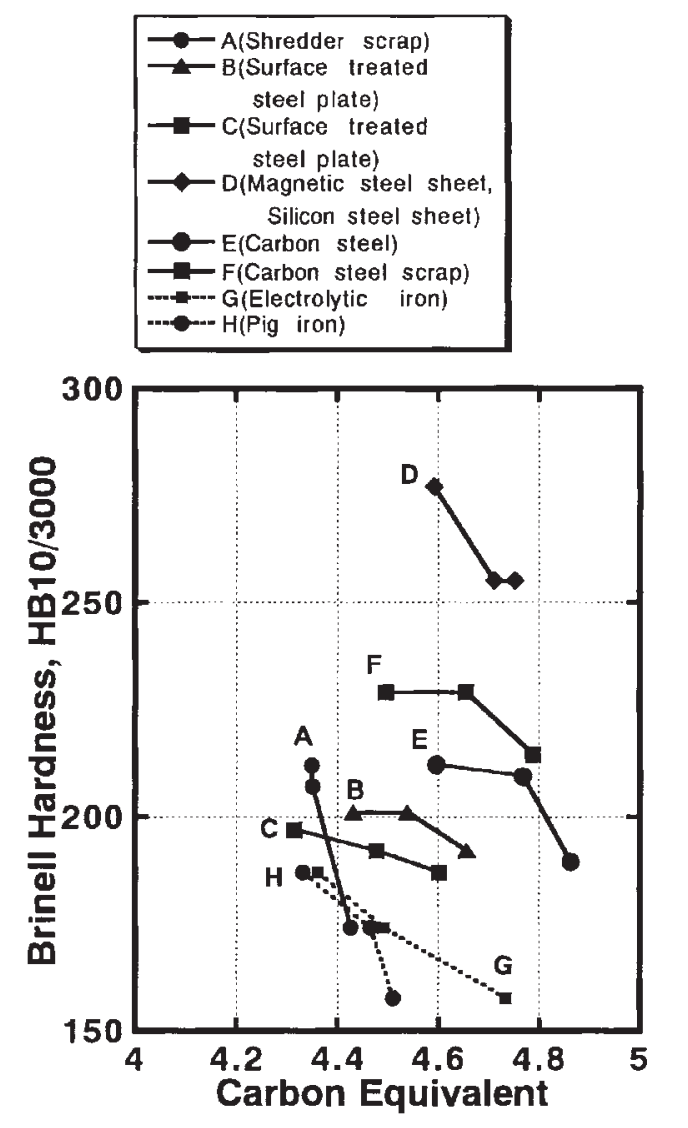

(=C $\%+0.31 \%$ Si-0.027\%Mn+0.33\%P+0.4\%S)

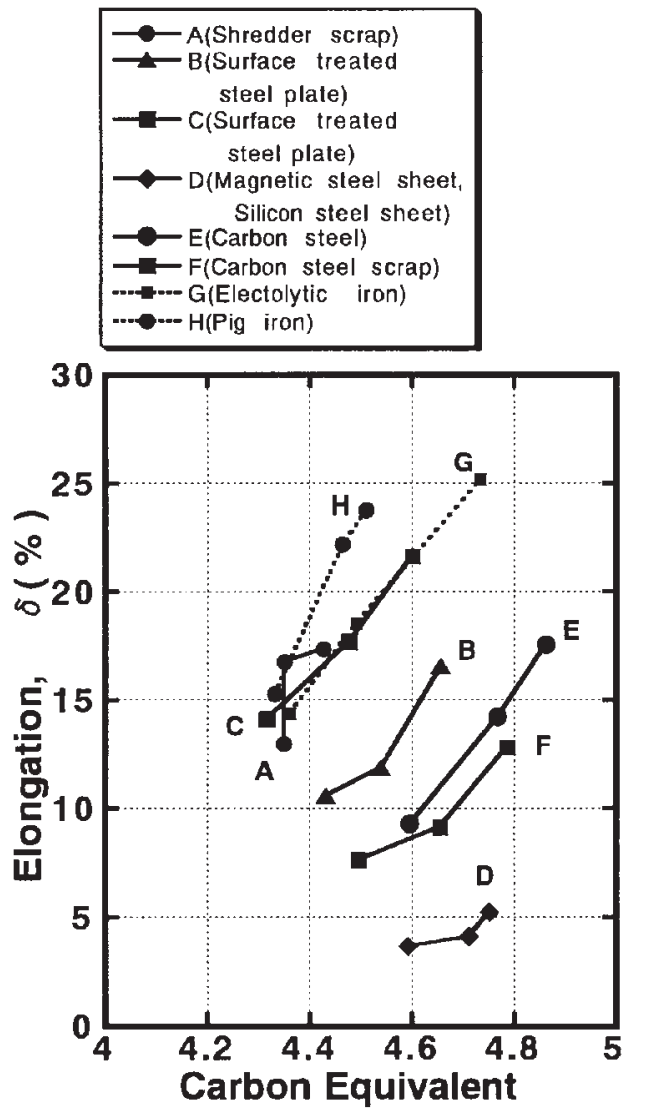

(=C $\%+0.031 \%$ Si-0.027\%Mn+0.33\%P+0.4\%S)

Fig. 3 Relation between elongation values and carbon equivalent.

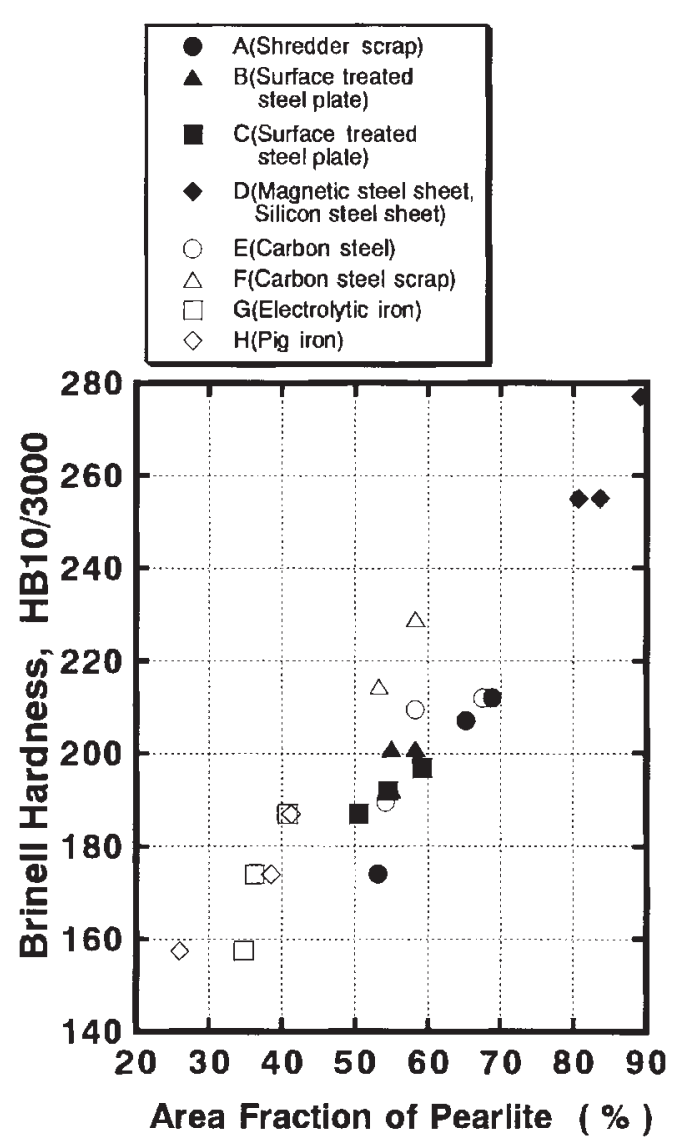

Fig. 5 Relation between area fraction of pearlite and Brinell hardness. 


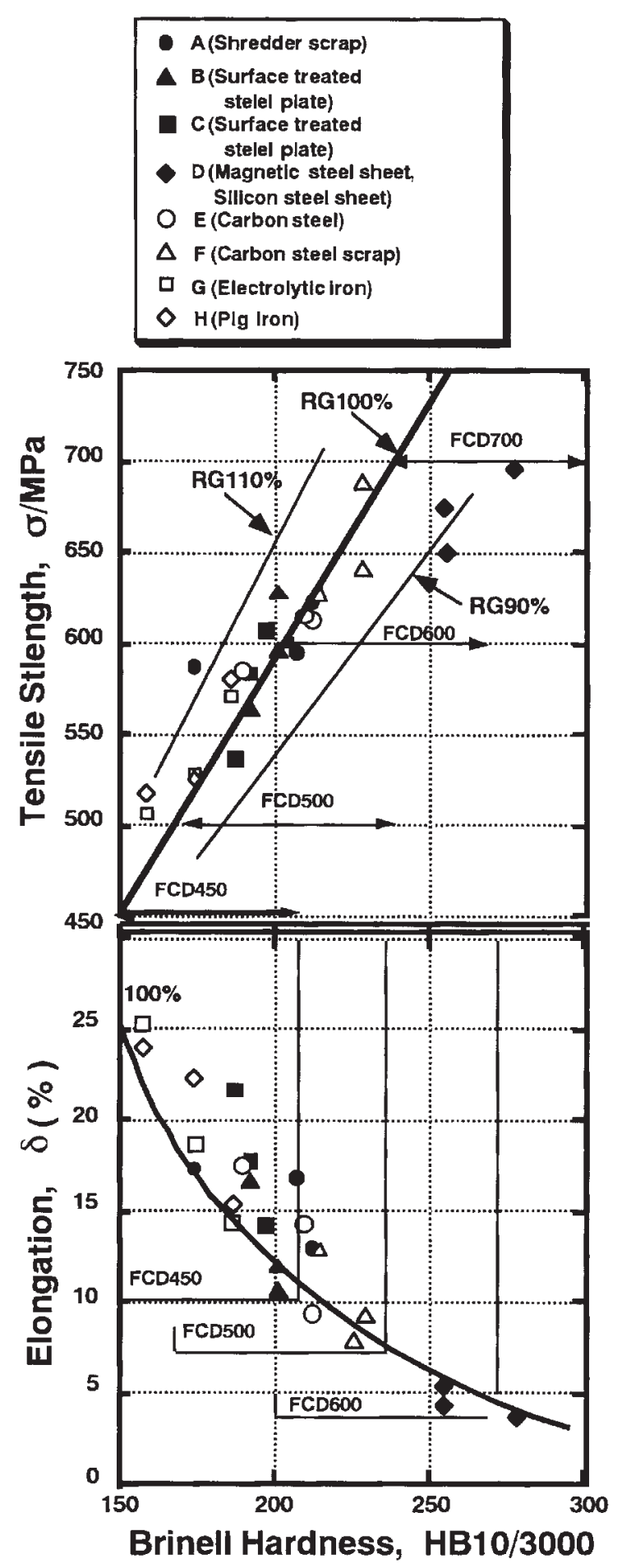

Fig. 6 Relation between tensile strength, elongation values and Brinell hardness.

Figure 6 shows relations between tensile strength, elongation values and Brinell hardness.

A linear relationship between tensile strength and Brinell hardness was obtained. The elongation values deceased oppositely. The results can be expressed as:

Tensile strength:

$$
\sigma\left(\mathrm{N} / \mathrm{mm}^{2}\right)=47.1+2.7 \times \mathrm{HB}
$$

Elongation:

$$
\begin{aligned}
& \ln \delta(\%)=5.02-0.013 \times \mathrm{HB} \\
& \operatorname{RG}(\%)=\left(\sigma_{\mathrm{t}} / \sigma_{\mathrm{n}}\right) \times 100
\end{aligned}
$$

$\sigma_{\mathrm{t}}:$ the standard tensile strength

$\sigma_{\mathrm{n}}$ : the actual tensile strength

$\mathrm{RG}^{12)}$ the reifegard, means the degree of normality. The concept of reifegrad is widely used for estimating the quality of flake graphite cast iron. According to this concept, quality is expressed by the comparison of the actual tensile strength with the standard tensile strength of the same carbon equivalent. Because the Brinell hardness properly expresses the state of matrix structure, the comparison of the actual tensile properties and standard properties for same Brinell hardness is considered to be reifegrad of spheroidal graphite cast iron.

Most specimens are RG100\% excepting the cast iron prepared with the magnetic steel sheet scrap. The antimony in the magnetic steel scrap deteriorates the morphology of spheroidal graphite. Therefore, tensile strength decreased in the same hardness due to morphological changes of spheroidal graphite.

The quality of castings may be defined, in general, as the capability of the parts to meet the microstructure and mechanical properties specifications with maintaining a high level of consistency for these properties. The results, herein described and discussed, confirm the influence of the steel scrap as a law charge material on the quality of spheroidal graphite cast iron. Through extended laboratory tests, they demonstrate that variation in chemical composition that appear meaningless, at first sight, may have significant effect on the microstructure and the mechanical properties.

When a materials property of cast iron is examined, it is important that the relation among tensile strength, elongation and hardness is clarified. Generally, the tensile strength increases with increasing the hardness value. A cast iron should be not hard from the machine processing side though the tensile strength should be high. From the experimental results, the tensile strength of all specimens was $450 \mathrm{MPa}$ or more. The tensile strength, the elongation and the hardness are evaluated synthetically; the specimens are classified into three grades, FCD450, FCD500 and FCD600. In the case of the magnetic steel sheet (D) is classified into FCD600 and the carbon steel scrap (F) is classified into FCD500 according to a JIS standard.

In consideration of material properties for iron castings to be demanded, it is important to understand the kind of scrap and the trace element of steel scrap. The stronger pearlite forming tendency of magnetic steel scrap based materials is due to the content of $0.2 \%$ antimony in the castings. Also the carbon steel scrap (high strength carbon steel) containing manganese and tin based materials are sufficient to favor pearlite formation.

The results of this study supported the beneficial role of materials in the charge to stabilize the concentration of pearlite-promoting elements and, thus, to improve the consistency of characteristic of the pearlitic castings. 


\section{Conclusions}

Based on the results obtained in this study, the following conclusions may be reached.

(1) The shredder scrap and zinc coated steel scrap deteriorated the morphology of spheroidal graphite, hence they lowered the tensile strength of cast iron in specimens.

(2) The yield rate of zinc is about $50 \%$. During melting in furnace, $50 \%$ of zinc became a zinc oxide.

(3) The magnetic steel sheets containing antimony produced considerable pearlite and resulted in significant increases in tensile strength with corresponding reductions in ductility.

(4) The carbon steel scrap and high strength steel scrap containing chromium, tin and manganese also produced considerable pearlite and resulted in significant increases in tensile strength.

(5) There are the casting prepared with surface treated steel sheet scrap to correspond the Japanese JIS FCD450 standard and the casting prepared with magnetic steel sheets not satisfied in the specimens. It is important for a sound cast iron to understand the kind of scrap and the trace element of steel scrap.

\section{REFERENCES}

1) A. Chida: Proceedings of AFS symposium (1980) 99.

2) K. H. Capers: Giesseri 63 (1973) 679.

3) H. Morrougt: AFS Trans. 60 (1952) 439

4) C. K. Donoho: Modern Castings 46 (1964) 608.

5) E. N. Pan, C. N. Lin and H. S. Chiou: AFS Trans. 103 (1995) 265-273.

6) H. Nakae, T. Kanno and B. Y. Kim: Proceedings, 2nd AFC (1994) $1-10$.

7) M. F. Nikolai, A. Javaid, M. P. Arvedson, C. Vaidyanathan and C. R. Loper. Jr.: AFS Trans. 102 (1994) 781-787.

8) M. Gagne: AFS Trans. 92 (1984) 387-393.

9) H. Horie: J. Japan Foundry Engineering 48 (1976) 629-634.

10) H. Morrougt: AFS Trans. 60 (1952) 439.

11) E. N. Pan and C. N. Lin: AFS Trans. 104 (1996) 845-858.

12) K. Ikawa: J. Japan Foundry Engineering 68 (1995) 883-890. 